\title{
Rhetorical tools in a collection of poems Masih Ingatkah Kau Jalan Pulang by sapardi djoko damono and rintik sedu
}

\author{
Rr. Purwanti ${ }^{1}$, Ratu Wardarita ${ }^{2}$, Arif Ardiansyah ${ }^{2}$ \\ ${ }^{1}$ Sekolah Menengah Pertama Negeri 1 Mesuji, Ogan Komering Ilir, Indonesia \\ ${ }^{2}$ Universitas PGRI Palembang, Indonesia
}

\section{Article Info \\ Article history: \\ Revised Aug $6^{\text {th }}, 2021$ \\ Keyword: \\ Rhetorical means \\ Form \\ Function \\ Dominant \\ Learning design}

Received Jul 20 $0^{\text {th }}, 2021$

Accepted Aug 30 $0^{\text {th }}, 2021$

\begin{abstract}
This study aims to analyze the form of rhetorical tools in a collection of poems Masih Ingatkah Kau Jalan Pulang by Sapardi Djoko Damono and Rintik Sedu. Data analysis was carried out in a descriptive-qualitative manner consisting of words, phrases, or sentences in poetry. The results of the research are in the form of rhetorical means, consisting of simile, metaphor, personification, and synecdoche display, repetition structure manipulation, parallelism, polysyndeton, asyndeton, hyperbole, rhetoric, and climax, as well as images of sight, hearing, smell, touch, and motion. The function of rhetoric means is to intensify, enliven, provide clarity of imaginary images, aesthetically, emphasize, rhetorically, generate more effective associations of meaning, make it concrete, and make it easier to imagine. The dominant use of rhetorical means, in structural manipulation, is parallelism and repetition, in images are images of motion, sight, and hearing, in a presentation are metaphors and personifications. The learning design in SMP must be studentcentered, paying attention to individual differences and selecting the right learning model.
\end{abstract}

(C) 2021The Authors. Published by IICET.

This is an open access article under the CC BY-NC-SA license (https://creativecommons.org/licenses/by-nc-sa/4.0

\section{Corresponding Author:}

Purwanti, R.,

Sekolah Menengah Pertama Negeri 1 Mesuji, Ogan Komering Ilir, Indonesia

Email: rrpurwanti.spd@gmail.com

\section{Introduction}

The beauty of language in poetry gives a distinctive style to the poetry to represent the thoughts and feelings of the poet. [1] poetry is a human creation in the form of an expression of the human soul which is displayed expressively in the form of beautiful language, aesthetic words, a series of elegant sounds, and has an appeal to readers.

The right words and language will be effective as a means of conveying the intended meaning of the poet. Effective language skills are called rhetoric. [2] rhetoric is a way of using language to obtain aesthetic effects. Lack of accuracy in the meaning of words can distance the meaning of the poem from the true meaning desired by the poet.

Associated with enjoyment and meaning of poetry, that $m$ embrace with real enjoyment will bring meaning experienced by the reader with meaning diluapkan by the poet. Poet is was rich in meaning. [1] humans have memorable experiences and are expressed in beautiful words that are rich in meaning. Unfortunately, poetry readers generally complete their reading activity, word for words like reading a novel or other story. Only a small part of them read part by section, absorbed, and interpreted to completion. 
At all levels of schooling, from school dasar, junior high school to high school. The learning materials range from reading, identifying, interpreting, to writing poetry. Its application in the field is not easy. Students do not easily understand the rhetorical elements in the poetry they are learning.

This collection of poetry Masih Ingatkah Kau Jalan Pulang, by Sapardi Djoko Damono and Rintik Sedu, is very strong, unique, inviting the reader to think about what the words mean, and at the end of the poem, there is a narrative.

Based on the above background, in the formula right the problem as follows. 1) What are the forms and meanings of rhetorical tools which include visualization, structural design, and imagery contained in the poetry collection Masih Ingatkah Jalan Pulang by Sapardi Djoko Damono and Rintik Sedu?. 2) What is the function of rhetorical tools which include visualization, structural design, and imagery contained in the poetry collectionMasih Ingatkah Jalan Pulang by Sapardi Djoko Damono and Rintik Sedu? 3) Which rhetorical instrument is dominant in the collection of poetryMasih Ingatkah Jalan Pulang by Sapardi Djoko Damono and Rintik Sedu?. 4) How is the rhetorical tool learning design in the poetry collection Masih Ingatkah Jalan Pulang by Sapardi Djoko Damono and Rintik Sedu?

Following the formulation of the problem, the objectives of this study are as follows. 1) Describe the form and meaning of rhetorical means which include visualization, structural design, and imagery contained in the poetry collection Masih Ingatkah Jalan Pulang by Sapardi Djoko Damono and Rintik Sedu. 2) Describe the function of rhetorical tools which include visualization, structural design, and imagery contained in the poetry collection Masih Ingatkah Jalan Pulang by Sapardi Djoko Damono and Rintik Sedu. 3) Describe the dominant rhetorical means contained in the collection of poetry Masih Ingatkah Jalan Pulang by Sapardi Djoko Damono and Rintik Sedu. 4) Creating a rhetoric tool lesson plan in a collection of poetry Masih Ingatkah Jalan Pulang by Sapardi Djoko Damono and Rintik Seduin junior high school.

\section{Method}

The method used is descriptive qualitative, with documentation techniques. Data in the form of words, phrases, and sentences from a collection of poetry objects of research

\section{Results and Discussions}

Through the stroke of a pen, humans can express thoughts and feelings according to their imagination. According to [3] Rhetoric is a way of using language to convince listeners or readers or to get mental and emotional effects or other effects. The rhetorical means of poetry is the language chosen by the poet to attract attention, thoughts so that the reader contemplates what is said by the poet. Thus, the reader will get the effect and intent of the poem according to what the poet wants.

\section{Form of Rhetoric Means}

The amount of data obtained so that in this discussion in each section one data is presented as a sample.

\section{a. Exposure}

A figure of thought is a language expression technique, grammar, whose meaning does not refer to the literal meaning of the words that support it, but to the added meaning, the implied meaning [4]

\section{1) Comparison}

[5] Comparison or parable or simile is a figurative language that equates one thing with another by using comparative words such as; like, as, like, like, for example, like, like, sepantun, jenaka, se, and other comparative words.

\section{2) Metaphor}

The definition of metaphor [9] metaphor is figurative language such as comparison, only does not use comparative words, such as like, like, bak, and so on. 
3) Personification. [5] Personification is a metaphor that equates inanimate objects being able to do, think, and other deeds as if they have human-like characteristics.

4) Sinekdoke. [5] Sinekdoke is a figure of speech that mentions an important part, an object (thing) for the thing or thing itself. Sinekdoke consists of two types, namely pars pro toto means part of the whole and total pro parte means whole for some.

b. Structural Strategy. [4] Structuring sentences are structures that are deliberately circumvented, manipulated, and empowered to obtain aesthetic effects.

1) Repetition. A repetition is a form of repeating words, phrases, or parts of sentences that are considered important for emphasis. Words or groups of words that are repeated in repetition can be in one or more sentences and can be in the initial, middle, or any final positions [4]

2) Parallelism. Parallelism (paralleling) is repeating the side of a sentence with the same purpose or parallel meaning [6]

3) Polisindenton. Polisindenton is a form of repetition using certain task words that link ideas, details, mentions, or others that are parallel or balanced [4].

4) Asindenton. [4] Asyndeton is a form of repetition in the form of using the punctuation "comma". ideas that are flanked by the form of repetition "and" or "comma" are equivalent [4]

5) Hyperbole. Hyperbole is a style used by poets to exaggerate a situation to emphasize the meaning, narrative, and aesthetic effect of the poem.

6) Rhetorical. Rhetorical is a type of structural circumvention in the form of rhetorical questions, questions that do not require an answer.

7) Climax. A climax is a form of structural circumvention by expressing ideas sequentially. Successive from the simplest to the desired point, from low the intensity increases.

c. Imagery. In poetry to give a clear picture, to create a special atmosphere, to make the image more vivid in the mind and senses, and also to attract attention, the poet uses imaginary images in addition to other poetic tools. The imagery (thoughts) are called imagery [6].

1) The images of Sight ( visual imagery ). Visual imagery is an image that arises from the perception of the sense of sight impression. "The visual image stimulates the sense of sight so that often things that are not seen become as if they are seen" [6].

2) The images of Hearing ( Auditory Imagery). The auditory image is an image that arises from the perception of the sense of hearing. Everything is related to the effort to provoke auditory imagery to evoke a certain atmosphere in poetry (Hasanudin, 2012: 119).

3) The images of Smell ( Smell Imagery ). Hasanudin (2012: 123) says that abstract ideas that poets try to concretize by depicting them or depicting them through stimuli that seem to be captured by the sense of smell.

4) Tactile / thermal imagery. The tactile image is an image that arises from the perception of the sense of touch. Hasanudin (2012: 127) explains that tactile imagery is an image in the form of a painting that can create an image of being touched, touched, or an activity that involves the sense of touch (skin).

5) The images of motion ( kinesthetic Imagery). The motion image is an image that arises from the imagination which describes something as if it is moving. According to Hasanudin (2012: 129), poets evoke emotions in poetry through something that is still as if it can move. 


\section{Rhetorical Means Functions}

Rhetoric means to have their respective functions according to the form of the rhetorical means.

a. Exposure Function

[6] the existence of this figurative language causes poetry to attract more attention, creates freshness, and especially gives rise to the clarity of imaginary images by confusing or equating things with other things so that the picture is clearer, more attractive, and alive.

From the results of the analysis, the function of the presentation in the collection of poetry Masih Ingatkah Kau Jalan Pulangby Spardi Djoko Damono and Rintik Sedu is to make poetry more interesting, more beautiful, fresher, clearer imagined, lively, intensive, and more concrete.

\section{b. Structural Worker Functions}

According to Nurgiyantoro (2017: 246), the structure is deliberately arranged by the author to obtain certain effects, especially aesthetic, rhetorical effects, to generate more effective, newer or fresher, and impressive meaning associations.

The function of structural tweaking in the collection of poetry Masih Ingatkah Kau Jalan Pulang by Sapardi Djoko Damono and Rintik Sedu is to emphasize, rhetorical, aesthetic effects, and to generate more effective meaning associations.

\section{c. Image Functions}

[6] in the hands of a good poet, the image is fresh and alive, at the peak of its beauty to intensify, clarify, enrich; an image that succeeds in helping people feel the author's experience of the objects and situations they experience, the memory of images that are precise, vivid, powerful, economical, and immediately we can feel and are close to life itself.

The function of imagery in a collection of poems Still Remember You Jalan Pulang, by Sapardi Djoko Damono and R Titik Sedu, is to concretize, intensify, clarify imaginary images, make it easier to imagine, and animate.

\section{Dominant Rhetoric Means.}

Rhetorical means that appear intensively or appear more frequently than others show that this is the dominant rhetorical tool in a poem. The use of display is 99 consisting of 2 similes, 48 metaphors, 41 personifications, and 8 synecdoches. In imaging, 140 uses consist of 47 visual images, 30 auditory images, 3 olfactory images, and as many sensory images as 7 , and motion imagery of 53 . The uses of structural circumvention were 183 consisting of 78 reps, 85 parallelisms, 1 polysyndeton, 3 asyndetons as much, 6 hyperbole, 9 rhetoric, and 1 climax. The use of 140 images consisted of 47 visual images, 30 auditory images, 3 olfactory images, 7 sense images, and 53 motion images. Thus, from the above discussion, the dominant use of rhetorical means is structural circumvention with the use of parallelism the most.

\section{Learning Design.}

Another definition, learning design or learning design is a process that involves teachers, students, interactions, materials, methods, and assessments [7]. Other RPP components by Permendikbud Number 22 of 2016 consist of school identity, subject identity or theme / sub-theme, class/semester, subject matter, time allocation, basic competencies and indicators of competency achievement, learning materials, learning methods, learning media, and Learning Resources..

\section{Conclusions}

Based on the results of the research and discussion, several essential things can be concluded. These things are as follows. The rhetorical tools used in the collection of poetry Still Remember You Jalan Pulang, by Sapardi Djoko Damono and Retakan Sedu, are in the form of visualization, structural tweaking, and imagery. The 
function of rhetorical tools in the collection of poetry Masih Ingatkah Kau Jalan Pulang by Sapardi Djoko Damono and Rintik Sedu is to intensify, enliven, provide clarity of imagery, aesthetically, emphasize, rhetorically, generate associations of meaning more effectively, concretize, and make imagining easier. The dominant use of rhetorical means in this collection of poetry is the structural circumvention of parallelism and repetition. Next, in imaging is motion and vision images. Furthermore, on display is metaphor and personification. Rhetoric learning in junior high schools according to the 2013 curriculum syllabus is designed to be implemented in class VIII semester odd. The learning design is prepared by taking into account the individual differences of students, active participation of students, student-centered, developing a culture of reading and writing, providing feedback and follow-up, emphasizing linkages and cohesiveness, accommodating integrated thematic learning, application of information technology and communication, and choosing the right learning model.

\section{References}

Andayani dan Kodrat E.P.S. 2019. Strategi Ampuh Memahami Makna Puisi. Cirebon: Eduvision. Nurgiyantoro, Burhan. 2010. Teori Pengkajian Fiksi. Yogyakarta: Gadjah Mada University Press. Abrams, M.H. 2015. A Glossary of Literary Terms. New York: Holt: Holt, Rinehart and Winston. Nurgiyantoro, Burhan. 2017. Stilistika. Yogyakarta: Gadjah Mada University Press.

Pradopo, Rahmat Djoko. 2013. Beberapa Teori Sastra, Kritik, dan Penerapannya. Yogyakarta: Pustaka Pelajar.

Pradopo, Rahmat Djoko. 2014. Pengkajian Puisi. Yogyakarta: Gadjah University Press.

Muslih, Aguslani dan Rudi ahmad Suryadi. 2019. Desain Perencanaan Pembelajaran. Yogyakarta: Depublish. 